Swarthmore College

Works

$12-1-2011$

\title{
Expanding The Temporal Dimensions Of Developmental Biology: The Role Of Environmental Agents In Establishing Adult-Onset Phenotypes
}

Scott F. Gilbert

Swarthmore College, sgilber1@swarthmore.edu

Follow this and additional works at: https://works.swarthmore.edu/fac-biology

Part of the Biology Commons

Let us know how access to these works benefits you

\section{Recommended Citation}

Scott F. Gilbert. (2011). "Expanding The Temporal Dimensions Of Developmental Biology: The Role Of Environmental Agents In Establishing Adult-Onset Phenotypes". Biological Theory. Volume 6, Issue 1. 65-72. DOI: $10.1007 / \mathrm{s} 13752-011-0008-0$

https://works.swarthmore.edu/fac-biology/379

This work is brought to you for free by Swarthmore College Libraries' Works. It has been accepted for inclusion in Biology Faculty Works by an authorized administrator of Works. For more information, please contact myworks@swarthmore.edu. 


\title{
Expanding the Temporal Dimensions of Developmental Biology: The Role of Environmental Agents in Establishing Adult-Onset Phenotypes
}

\author{
Scott F. Gilbert
}

Received: 21 May 2011/Accepted: 23 May 2011/Published online: 8 November 2011

(C) Konrad Lorenz Institute 2011

\begin{abstract}
Developmental biology is expanding into several new areas. One new area of study concerns the production of adult-onset phenotypes by exposure of the fetus or neonate to environmental agents. These agents include maternal nutrients, developmental modulators (endocrine disruptors), and maternal care. In all three cases, a major mechanism for the generation of the altered phenotype is chromatin modification. Nutrient conditions, developmental modulators, and even maternal care appear to alter DNA methylation and other associated changes in chromatin that regulate gene expression. This brings a new, under-appreciated, dimension of gene regulation into developmental biology, and it also demonstrates the poverty of the nature versus nurture framework for discussing phenotype production. Moreover, while such epigenetic mechanisms undermine genetic determinism, they add a layer of probabilistic biological causality for the maintenance of social inequalities.
\end{abstract}

Keywords Behavior - Development - Developmental origins of adult disease $\cdot$ Environmental causation .

Epigenetic $\cdot$ Nature-nurture $\cdot$ Nutrition $\cdot$ Plasticity

\section{The Expansion of Developmental Biology}

Developmental biology is redefining its limits as it expands into new areas. Traditionally, embryology,

S. F. Gilbert $(\bowtie)$

Department of Biology, Swarthmore College, Swarthmore,

PA, USA

e-mail: sgilber1@swarthmore.edu

\section{S. F. Gilbert}

Biotechnology Institute, University of Helsinki, Helsinki, Finland whether conceived as comparative embryology or physiological embryology, had limited itself to the ontogenetic stages of individual organisms. "Developmental biology" was a term invented twice, each time for a different expansion. In the 1950s, this term was used by Paul Weiss $(1956,1959)$ and N. J. Berrill (personal communication, ca. 1981) to expand the temporal limits of development into the adult. ${ }^{1}$ Regeneration and hematopoiesis were seen as developmental processes, though not confined to the embryo. In the mid-1960s, the term "developmental biology" was reapplied when developmental biology added the cellular and molecular levels of explanation to the physiological and anatomical levels (Lederberg 1966; Moscona and Monroy 1966). Here, microbial systems could be used to model gene regulation, and development was seen to involve not merely embryos but also slime molds, adult blood cell formation, cancers, and regenerating tissues.

We are now appreciating that animal development includes more processes than we had known, and the field of developmental biology is thus expanding in even more directions. The molecular dimension is being expanded through connections to physical chemistry. The interactions between transcription factors, their DNA enhancer sites, other transcription factors, and nucleosome modulating factors is becoming a study of dissociation constants and protein surface chemistry. The past generation had identified the players. The new generation comprehends

\footnotetext{
$\overline{1}$ N. J. Berrill told me that Weiss had written him asking for advice as to what to title his new series that would include not only embryology, but also regeneration, colonial organism formation, and other aspects of developmental biology. Berrill said that he capitalized the first letters of "developmental biology" and sent the letter back.
} 
that understanding these interactions demands knowledge of hydrophobic binding surfaces and other such physical states. The comparative dimension of developmental biology is expanding as evolutionary developmental biology. Here, the combination of regulatory gene function, paracrine interactions, genomics, and mathematical modeling is forging a science that can explain the origins of evolutionary novelty and point toward a developmental explanation of biodiversity-both how the current biodiversity appeared and why other types of biodiversity do not.

Developmental biology is also expanding rapidly in the spatial dimension. First, ecological developmental biology ("EcoDevo") has shown that the developing organism does not exist as an isolated entity. Developmental plasticity has been shown to be the rule, not the exceptional case. Phenomena such as temperature-dependent sex determination or diet-dependent morphologies had been considered unusual departures from the gene-directed script. Now, however, research documents that organisms have routinely evolved mechanisms to receive cues from their environment that alter development to enable the organism to be more robust in that particular habitat. Thus, the developing organism can sense predators and alter its development to avoid or evade them. Diet, temperature, stress, conspecifics, temperature, and even mechanical pressure each can become a signal that can be utilized for altering development (Gilbert 2002, 2012; Gilbert and Epel 2009). Second, organisms have outsourced many essential developmental signals to microbes (McFall-Ngai 2002; Saffo 2006; Rosenberg et al. 2009; Gilbert and Epel 2009; Pradeu 2011, this issue). This also expands the spatial dimension of development to include "outside" organisms intimately. We are built not by one genome but by hundreds, if not thousands (see Mazmanian 2010).

In addition, a remarkable temporal expansion of developmental biology is also occurring. The most obvious temporal expansion has been in the area of stem cells and regeneration. Here, a population of multipotent or unipotent cells remains in an undifferentiated state throughout the lifetime of the organism (see the discussion of this question by Laplane 2011, this issue). The surrounding cells create an embryonic-like "niche" that keeps the stem cells in this relatively undifferentiated state. When cell division occurs, some of these cells escape the domain of the niche and start to differentiate, while others of these cells remain in the niche and continue to be stem cells. In this way, development is seen to persist into adulthood, and even aging syndromes and cancers may be caused by the failure of the niches to properly regulate stem cell proliferation (Gilbert 2010; Voog and Jones 2010; see also the discussion of aging by Morange 2011, this issue). Indeed, the symbiotic microbes of the gut may play a role in the intestinal stem cell niche, regulating the proliferation of its stem cells and (usually) preventing cancers (Sun 2010).

But there is another set of conditions that has caused the temporal expansion of developmental biology into adulthood. These involve the unexpected conclusions that some events that occur early in development have phenotypic consequences that are not seen at birth. Rather than being congenital, these phenotypic alterations are perceived only much later in life. I will discuss three such epigenetic conditions that affect and effect adult mammalian phenotypes: antenatal nutrition, developmental modulators, and maternal care. (Mammalian development will be highlighted because of the familiarity with vocabulary, not for any particular scientific reason). After these are discussed, I will present evidence that yet another temporal expansion of developmental biology is being generated; namely that the effects of these three conditions can also be transgenerational. In other words, the conditions affecting the prenatal or perinatal period affect not only the phenotype of the developing organism, but also the phenotypes of subsequent generations.

\section{Nutrition and the Fetal Origins of Health and Disease}

Developmental plasticity is one of the most interesting set of evolutionary adaptations. Organisms have evolved to sense cues from their immediate environment and to enter a developmental trajectory that will enhance their ability to survive in that particular environment (Nicoglou 2011, this issue). Thus, the genotype encodes a repertoire of phenotypes, and the environment instructs the development of a particular phenotype out of this universe of possibilities. The cues can come from biotic sources such as predators or competitors, or they can come from temperature, photoperiod, or some other abiotic source. Often, as in the case of amphibian tadpoles or snails, the developing organism integrates cues from several sources to affect a phenotype (Relyea and Hoverman 2003; Hoverman and Relyea 2007; Gilbert and Epel 2009).

These external cues often give the animal a signal as to the state of its future environment. Thus, an immature Daphnia can develop defensive structures such as protective helmets and spiked tails when it encounters signals from its major predator. A Bicyclus butterfly larvae experiencing warm temperatures will develop wings with eyespots to deflect the predators it will encounter during the summer months (Gilbert 2002; Miyakawa et al. 2010; Beldade et al. 2011). These alterations of development are called predictive adaptive responses (Gluckman and Hanson 2004, 2007).

Hales and Barker $(1992 ; 2001)$ have proposed a "thrifty phenotype" hypothesis, wherein a malnourished fetus 
makes a predictive adaptive response to expect a nutrientdeficient environment. The paucity of nutrition sets the molecular parameters of the cells to conserve energy and to store fat. In other words, the embryo has phenotypic plasticity wherein it can modulate its phenotype depending on the nutritional environment. If it experiences a low caloric environment, it will create and enter a developmental trajectory that will allow it to use the calories it gets more efficiently.

Nutrition can accomplish this feat by altering the chromatin conformation of particular genes. One mechanism for accomplishing this is to regulate the amount of a particular protein by methylating or demethylating the regulatory regions of critical genes. DNA methylation (and its associated effects on the chromatin proteins) is the "standard" way that differential gene expression takes place in the developing mammal. Those genes whose regulatory regions are heavily methylated are shut down, while those genes whose regulatory regions are relatively unmethylated are active. Moreover, this pattern of DNA methylation becomes specific to a particular cell type and is stably inherited when the cells divide.

Studies have shown that the diet experienced by a pregnant mammal can be sensed by the embryo. Within the embryo, the diet can alter the DNA methylation pattern of particular genes involved in fat and carbohydrate synthesis. Mice born of mothers given a low protein diet during gestation have a different pattern of liver gene methylation than did the offspring of mothers fed a diet with a normal amount of protein, and these differences in methylation changed the metabolic profile of the mouse's liver. For instance, the methylation of the promoter region of the $\operatorname{PPAR} \alpha$ gene (a gene that is critical in the regulation of carbohydrate and lipid metabolism) is $20 \%$ lower in those rats fed protein-restricted diets and its activity is tenfold greater (Lillycrop et al. 2005, 2010). In addition, the promoter region of the glucocorticoid receptor gene (critical in blood pressure regulation and starch storage) was $22 \%$ less methylated and three times more transcriptionally active in the pups born of mothers given a protein-restricted diet (Burdge et al. 2007a). These methylation patterns persisted after the dietary restrictions ceased, thereby showing stable modifications in gene expression due to nutritional influences. DNA methylation thereby provides a mechanism for fetal alterations to persist throughout life.

If the fetus has made an accurate prediction, and the young mouse does indeed find itself in this expected poor environment, it is ready for it and can survive better than if its metabolism had been set to utilize energy and not store it as efficiently. However, if such a mouse lives in an energy- and protein-rich environment, its cells store more fats than they otherwise would have, and its heart and kidney have grown for more stringent conditions. The
DNA methylation pattern established in utero will now predispose this mouse to hypertension, obesity, and diabetes. But, as Gluckman and Hanson $(2004,2007)$ have pointed out, these diseases come late in life, after reproduction has occurred. Evolution values the fitness of juveniles more than the health of post-reproductive adults.

\section{Endocrine Disruptors: Modulating Developmental Trajectories}

Teratology has been a major part of medical embryology. It is the study of how environmental agents cause birth defects. These teratological agents include ethanol, retinoic acid, lead, radiation, and biological agents such as rubella. These are the agents that pregnant women are told to avoid. However, there is a newly discovered class of environmental agents that do not act as classical teratogens. These agents are called "endocrine disruptors," since most of them can alter hormonal activity. However, this endocrine disruption may only be part of what they do, and the term "developmental modulator" is perhaps more appropriate.

Developmental modulators differ from classical teratogens in at least four important ways (Myers et al. 2009; reviewed in Gilbert and Epel 2009):

(1) Classical teratogens comprise a relatively small group of "bad actors," such as lead, ethanol, and retinoic acid. Developmental modulators comprise a relatively large set of compounds including bisphenol-A (BPA), the polychlorinated biphenyls, phthalates, the dioxins, diethylstilbestrol, and numerous other compounds.

(2) The exposure to classical teratogens is relatively avoidable and usually in high doses due to accident or occupation. Exposure to developmental modulators is ubiquitous, since they are major components of plastics, sealants, food containers, cosmetics, herbicides, and pesticides. Developmental modulators include very important components of the technological environment into which we are born and raised.

(3) While classical teratogens are seen one at a time, developmental modulators are almost always experienced as mixtures.

(4) Classical teratogens disrupt development to produce anatomically observable birth defects. These are congenital malformations. Developmental modulators do not usually produce phenotypic disruptions until much later in postnatal life. Moreover, these effects are usually physiological disruptions of function rather than anatomical disruptions of structure.

Bisphenol-A has received much publicity, and one of the reasons scientists want to ban this compound is because of its temporal effects on development (Vom Saal et al. 
2007). Exposure around the time of birth causes anatomical and physiological alterations of the rat mammary glands. Their terminal buds become more numerous, and they have many more receptors for estrogen than the mammary gland epithelium of untreated newborn rats (Durando et al. 2007; Wadia et al. 2007). Moreover, the mammary glands seem "primed" for cell division. Addition of small amounts of estrogen or sub-threshold levels of carcinogen produce cancers in these mammary glands, but not in the untreated mammary glands (Vandenberg et al. 2008; Soto and Sonnenschein 2010). Prenatal and perinatal exposures to BPA have been linked to several anatomical and physiological problems later in life. These problems include abnormal penile/urethral development in males, early puberty in females, childhood and adult obesity, Type 2 diabetes mellitus, decreases in sperm count, increased hormonally mediated cancers such as prostate and breast cancers, brain abnormalities, altered sexual behaviors, and immune dysfunction (Kundakovic and Champagne 2011).

Moreover, in addition to its function as an endocrine disruptor, BPA also appears to alter the DNA methylation of several genes, including two that have been linked to cancers in the male and female reproductive systems (Ho et al. 2006; Dolinoy et al. 2007; Bromer et al. 2010). The European Union and Canada have banned this material from baby bottle plastics; the United States has not.

Another, but less publicized, of these developmental modulators is tributyl tin (TBT). This compound had been used as an anti-fouling agent for the hulls of ships, until it was found to be an endocrine disruptor, converting testosterone into estrogen and changing the sex of the mollusks living near the shipyards (Oberdörster and McClellan-Green 2002). TBT also has been used as an ingredient in fungicides, wood preservatives, and heat stabilizers in plastics. When drunk by a pregnant mouse, however, TBT makes its pups obese. It does this by altering the development of these mice by activating a transcription factor, $\operatorname{PPAR} \gamma$. PPAR $\gamma$ is a protein that is usually activated by the binding of fatty acids, and it is the major "obesogenic" protein in the body. When it is activated in mesenchymal stem cells, PPAR $\gamma$ instructs the descendents of these cells to become adipose (fat) cells instead of becoming bone cells or cartilage cells, the two other main derivatives of the mesenchymal stem cell. Furthermore, activated PPAR $\gamma$ activates the genes involved in fat synthesis and storage. And to make matters even more biased, TBT demethylates the region of DNA regulating the $\operatorname{PPAR} \gamma$ gene, making PPAR $\gamma$ even more abundant in the cell (Grün et al. 2006; Kirchner et al. 2010).

By altering the commitment of mesenchymal cells toward the adipose fate, TBT causes the embryo to make a larger number of fat cells. By activating the fat synthesis and storage genes, it makes them functional. The percentage of obese Americans has increased from 15\% in 1980 to 34\% in 2008 (Flegal et al. 2010). If the number of fat cells at birth is a major factor of adult obesity (see Janesick and Blumberg 2011a, b), then epigenetic models of obesity should certainly be studied as much as genetic (see Martinez-Hernandez et al. 2007) or lifestyle (see Vermorel et al. 2005) models. Embryonic exposure to an environmental agent can have a major effect on the adult phenotype years later.

\section{Maternal Care and DNA Methylation}

One of the mainstays of genetic determinism has been the alleles that give variations of behavior. Usually, one of the alleles of a particular gene produces a highly aberrant behavior showing that without the wild-type gene product, behavioral pathologies can result. Epigenetic research has shown, however, that the reverse is just as true, and perhaps more important. Namely, changes in behavior can initiate changes in chromatin. These changes involve the methylation of DNA and the methylation and acetylation of histones in the regulatory regions activating particular hormone receptor genes.

Studies done in the laboratories of Michael Meany and Frances Champagne have shown that the levels of maternal care are reflected in the chromatin of certain genes involved in rat behaviors. Specifically, they have shown that low levels of maternal care (mostly licking and grooming) to the rat during its first seven days after birth correlate with the methylation of regulatory regions of the genes encoding estrogen receptor-alpha and the glucocorticoid receptor (Weaver et al 2004; Weaver 2007; Champagne et al. 2006; Cameron et al. 2008). The low amount of licking and grooming causes the methylation of those regulatory regions that would otherwise permit the expression of these genes in the rat brain. Thus, not only do alterations in the DNA (different alleles) cause changes in behavior, but different levels of maternal behavior can cause changes in the (methylation and activation of the) DNA. One can turn off a gene as readily by methylation as by mutation.

High levels of maternal care lead to the demethylation of promoter regions of the rat glucocorticoid receptor gene, leading to the abundance of glucocorticoid receptor protein in the hippocampus. This, in turn, leads to the ability to downregulate the stress response in adult rats. Those rats experiencing low levels of maternal care thus become more "anxious as adults." In rats, high levels of maternal care also cause demethylation of the regulatory regions of the estrogen receptor genes, enabling their expression in the MPOA region of the brain that is associated with sexspecific behaviors. These differences, moreover, are not 
"good and bad," "normal and pathological." Rather, they are variations that may become advantageous in different environments. Those female rats with low estrogen receptors in the MPOA region of the brain have a more receptive sexual phenotype than the rats that had been licked and groomed thoroughly when young. This is not a pathology but a norm of behavior. Similarly, those rats whose lack of licking and grooming lowered the level of hippocampal glucocorticoid receptors get anxious more quickly and lose their anxiety more slowly. Again, this is not a "bad" phenotype; it is part of the normal variation in a population.

Thus, both bottom-up and top-down causation can readily be seen. The environment can regulate gene expression, and those events experienced during early development can become manifest as phenotypes much later in the history of the animal. In mammals, we have seen that this is the case with intrauterine nutrition, developmental modulators, and maternal care.

\section{Transgenerational Epigenetic Inheritance}

And as detective Columbo said, "Just one more thing." These effects can be transmitted from generation to generation. The Weismannian block to the transmission of acquired traits is a genetic block. A lifetime of chopping wood will not give your offspring bulging biceps; nor would the loss of one's arms in an accident cause one's offspring to have a propensity for limblessness. This is because the environmental agent does not cause mutations in the DNA. And mutations, if they are to be transmitted, must not only be somatic, but they must enter the germline. So mutations acquired in the skin by being in sunlight will not be transmitted.

However, DNA methylation seems to be a mechanism that can circumvent that block. Certain agents can cause the same alterations of DNA methylation throughout the body, and these alterations in methylation can be transmitted by the sperm and egg. Jablonka and Raz (2009) have documented dozens of such cases wherein different "epialleles," DNA containing different methylation patterns, can be stably transmitted from generation to generation. In the case of plants, one such epiallele (which confounded Linnaeus) appears to have been stably transmitted for over 250 years (Cubas et al. 1999). In mammals, epiallelic inheritance was first documented by studies of the endocrine disruptor vinclozolin, a fungicide used widely on grapes. When injected into pregnant rats during particular days of gestation, vinclozolin will cause testicular dysgenesis in the male offspring. The testes will start forming normally, but as the mouse gets older, its testes degenerate and no more sperm is made. What's more interesting is that the male mice born to those mice that get testicular dysgenesis also get testicular dysgenesis. So do their male offspring and the subsequent generation's male offspring (Anway et al. 2005, 2006; Guerrero-Bosagna et al. 2010). Thus, when a pregnant rat is given vinclozolin, its "great-grandsons" are still affected.

The mechanism for this transgeneration inheritance appears to be chromatin modifications, especially DNA methylation. Dozens of genes have their methylation pattern changed by vinclozolin, and these alterations can be seen in the sperm DNA for at least four generations. These genes include those whose products are necessary for cell proliferation, G-proteins, ion channels, and receptors. It is important to note that by the third generation, there can be no direct exposure to vinclozolin. The fetus is inside the treated dam; the fetus has germ cells (of the F2 generation) inside itself. But, the offspring of the F3 and F4 generations have never seen vinclozolin. Still, their phenotype is changed by the initial injection to their great-grand-dam. Similar studies (although not as extensive) have indicated that other endocrine disruptors-diethylstilbestrol and BPA, and PCBs-may also have transgenerational effects (Skinner et al. 2010; Walker and Gore 2011).

Nutritional epigenetic changes may also be transmitted from one generation to the next. Here, the evidence is sparser than in the cases of developmental modulators. In one instance, analysis of medical records from an isolated community in northern Sweden showed that the paternal grandfather's food supply during mid-childhood is linked to a greater risk of early deaths in grandsons (but not granddaughters). Conversely, the paternal grandmother's nutrition during middle childhood is reflected in the mortality risk of her granddaughters (and not her grandsons). This effect was not observed in the maternal grandmother or maternal grandfather, indicating that the influence was coming from the father of the children (Kaati et al. 2007; Pembrey 2010). Burdge et al. (2007b) showed that when a pregnant rat is given a low calorie diet, the promoters of the genes for the glucocorticoid receptor and $\operatorname{PPAR} \alpha$, two transcription factors involved in fat metabolism, are hypomethylated in her 80-day grand-offspring.

One of the most interesting cases, though, of the hereditary transmission of environmentally altered behavior comes from behavioral studies (Champagne and Meaney 2007; Champagne 2008). Not only do these studies provide a mechanism for such inheritance; they also show its malleability. First, in the case of rat estrogen receptor genes, the methylation pattern of the DNA and the phenotype of an adult rat's behavior can be shown to be due to the nursing it receives and not from its biological parent. This can be demonstrated by cross-fostering, wherein the pups of a high licking and -grooming mother are transferred at birth to a low licking and -grooming 
mother, and vice versa. The offspring take on the attributes (both molecularly and phenotypically) of the nursing parent, not their biological mother. This shows the malleability of such imprints. However, in a "normal" situation, where the pups are cared for by their biological mother, the high licking and -grooming mothers produce offspring with high levels of brain estrogen receptors and glucocorticoid receptors. In females, this normally translates into mother rats that give high levels of maternal care. And so the trait is passed on from generation to generation. Individual differences in rat maternal care can also be influenced by the environment, as chronic stress decreases the frequency of licking and grooming.

Although we have examples where the environment can produce effects that are transmitted through the germline, these are not "Lamarckian." Nowhere here is there a sense of physiological use or disuse being transmitted, nor is there any case of "willing" a phenotype into existence. No gemmules are propagated. Rather, this, like the case of symbionts, is an example of a mode of inheritance that parallels and interacts with the allelic mode. Moreover, the extension of development into ecological and transgenerational areas brings us to some critical social issues. The demographic heterogeneity of diet and endocrine disruptors has important implications for environmental justice (Landrigan et al. 2010; Su et al. 2011). Environmentally induced epigenetic changes in DNA (from psychological assault and maternal diet) have been documented in human populations (McGowan et al. 2009; Godfrey et al. 2011). This means that environmentally altered development may be a source for disparities in human populations. Sources of pollutants containing developmental modulators are often placed in the neighborhoods of those without political power, and pollutants will produce physical and cognitive deficits that promote the continuation of poverty. Lifestyles may also create conditions where developmental modulators, such as parabens and phthalates, are concentrated in specific populations. Moreover, given the prevalence of developmental modulators in our environment, and the presence of folate (methyl donor) in the diet of pregnant women, we are doing a biological experiment unprecedented in scope and size.

However, "epigenetic determinism" should be avoided as much as "genetic determinism." Just as the genes do not control one's destiny, neither does the environment. In the Mütter Museum in Philadelphia stands the plaster-of-Paris death cast of Eng and Chang Bunker, the "original" Siamese twins, who toured with P. T. Barnum. Eng was quiet, cheerful, and did not drink alcohol, while Chang was moody and drank heavily (see Wallace and Wallace 1979; Gould 1985). These brothers had the same genetic endowment (they were identical twins) as well as the same environmental exposures (they could not be apart from one another). Yet, they were very different people. Plasticity involves more than additive components, and the development of phenotypes is certainly not determined at fertilization or at birth.

\section{References}

Anway MD, Cupp AS, Uzumcu M, Skinner MK (2005) Epigenetic transgenerational actions of endocrine disruptors and mate fertility. Science 308:1466-1469

Anway MD, Memon MA, Uzumcu M, Skinner MK (2006) Transgenerational effect of the endocrine disruptor vinclozolin on male spermatogenesis. J Androl 27:868-879

Beldade P, Mateus AR, Keller RA (2011) Evolution and molecular mechanisms of adaptive developmental plasticity. Mol Ecol 20:1347-1363

Bromer JG, Zhou Y, Taylor MB, Doherty L, Taylor HS (2010) Bisphenol-A exposure in utero leads to epigenetic alterations in the developmental programming of uterine estrogen response. FASEB J 24(7): 2273-2280

Burdge GC, Hanson MA, Slater-Jefferies JL, Lillycrop KA (2007a) Epigenetic regulation of transcription: a mechanism for inducing variations in phenotype (fetal programming) by differences in nutrition during early life? Br J Nutr 97:1036-1046

Burdge GC, Slater-Jefferies J, Torrens C, Phillips ES, Hanson MA, Lillycrop KA (2007b) Dietary protein restriction of pregnant rats in the F0 generation induces altered methylation of hepatic gene promoters in the adult male offspring in the F1 and F2 generations. Br J Nutr 97:435-439

Cameron NM, Shahrokh D, Del Corpo A, Dhir SK, Szyf M, Champagne FA, Meaney MJ (2008) Epigenetic programming of phenotypic variations in reproductive strategies in the rat through maternal care. J Neuroendocrinol 20:795-801

Champagne FA (2008) Epigenetic mechanisms and the transgenerational effects of maternal care. Front Neuroendocrinol 29: 386-397

Champagne FA, Meaney MJ (2007) Transgenerational effects of social environment on variations in maternal care and behavioral response to novelty. Behav Neurosci 121:1353-1363

Champagne FA, Weaver IC, Diorio J, Dymov S, Szyf M, Meaney MJ (2006) Maternal care associated with methylation of the estrogen receptor-alphalb promoter and estrogen receptor-alpha expression in the medial preoptic area of female offspring. Endocrinology 147:2909-2915

Cubas P, Vincent C, Coen E (1999) An epigenetic mutation responsible for natural variation in floral symmetry. Nature 401: $157-161$

Dolinoy DC, Huang D, Jirtle RL (2007) Maternal nutrient supplementation counteracts bisphenol A-induced DNA hypomethylation in early development. Proc Natl Acad Sci USA 104:13056-13061

Durando M, Kass L, Piva J, Sonnenschein C, Soto AM, Luque EH, Muñz-de-Toro M (2007) Prenatal bisphenol A exposure induces preneoplastic lesions in the mammary gland in Wistar rats. Environ Health Perspect 115:80-86

Flegal KM, Carroll MD, Ogden CL, Curtin LR (2010) Prevalence and trends in obesity among US adults, 1999-2008. J Am Med Assoc 303:235-241

Gilbert SF (2002) The genome in its ecological context: philosophical perspectives on interspecies epigenesis. Ann N Y Acad Sci 981:202-218

Gilbert SF (2010) Developmental biology, 9th edn. Sinauer Associates, Sunderland 
Gilbert SF (2012) Developmental biology: Interpreting developmental signals. In: Kull K, Hofmeyer J (eds) Approaches to the Semiosis of Evolution (in press)

Gilbert SF, Epel D (2009) Ecological developmental biology. Sinauer Associates, Sunderland

Gluckman PD, Hanson MA (2004) Living with the past: evolution, development, and patterns of disease. Science 305:1733-1736

Gluckman PD, Hanson MA (2007) Mismatch: why our world no longer fits our bodies. Oxford University Press, Oxford

Godfrey KM, Sheppard A, Gluckman PD, Lillycrop KA, Burdge GC, McLean C, Rodford J, Slater-Jefferies JL, Garratt E, Crozier SR, Emerald BS, Gale CR, Inskip HM, Cooper C, Hanson MA (2011) Epigenetic gene promoter methylation at birth is associated with child's later adiposity. Diabetes 60:1528-1534

Gould SJ (1985) Living with connections. In: The Flamingo's Smile, Norton, New York, pp 64-77

Grün F, Watanabe H, Zamanian Z, Maeda L, Arima K, Cubacha R, Gardiner DM, Kanno J, Iguchi T, Blumberg B (2006) Endocrinedisrupting organotin compounds are potent inducers of adipogenesis in vertebrates. Mol Endocrinol 20:2141-2155

Guerrero-Bosagna C, Settles M, Lucker B, Skinner MK (2010) Epigenetic transgenerational actions of vinclozolin on promoter regions of the sperm epigenome. PLoS One 5(9)

Hales CN, Barker DJ (1992) Type 2 (non-insulin-dependent) diabetes mellitus: the thrifty phenotype hypothesis. Diabetologia 35: 595-601

Hales CN, Barker DJ (2001) The thrifty phenotype hypothesis. Br Med Bull 60:5-20

Ho S-M, Tang W-Y, Belmonte de Frausto J, Prins GS (2006) Developmental exposure to estradiol and bisphenol A increases susceptibility to prostate carcinogenesis and epigenetically regulates phosphodiesterase type 4 variant 4 . Cancer Res 66: $5624-5632$

Hoverman JT, Relyea RA (2007) The rules of engagement: how to defend against combinations of predators. Oecologia 154: $551-560$

Jablonka E, Raz G (2009) Transgenerational epigenetic inheritance: prevalence, mechanisms, and implications for the study of heredity and evolution. Q Rev Biol 84:131-176

Janesick A, Blumberg B (2011a) Minireview: PPAR $\gamma$ as the target of obesogens. J Stero Biochem Mol Biol 27:4-8

Janesick A, Blumberg B (2011b) Endocrine disrupting chemicals and the developmental programming of adipogenesis and obesity. Birth Defects Res C Embryo Today 93:34-50

Kaati G, Bygren LO, Pembrey M, Sjostrom M (2007) Transgenerational response to nutrition, early life circumstances and longevity. Eur J Hum Genet 15:784-790

Kirchner S, Kieu T, Chow C, Casey S, Blumberg B (2010) Prenatal exposure to the environmental obesogen tributyltin predisposes multipotent stem cells to become adipocytes. Mol Endocrinol 24:526-539

Kundakovic M, Champagne FA (2011) Epigenetic perspective on the developmental effects of bisphenol-A. Brain Behav Immun 25:1084-1093

Landrigan PJ, Rauh VA, Galvez MP (2010) Environmental justice and the health of children. Mt Sinai J Med 77:178-187

Laplane L (2011) Stem cells and the temporal boundaries of development: Toward a species-dependent view. Biol Theory. doi:10.1007/s13752-011-0009-z

Lederberg J (1966) Remarks. In: Monroy A, Moscona AA (eds) Current Topics in Developmental Biology. Academic press, New York, $\mathrm{p}$ ix-xiii

Lillycrop KA, Phillips ES, Jackson AA, Hanson MA, Burdge GC (2005) Dietary protein restriction of pregnant rats induces and folic acid supplementation prevents epigenetic modification of hepatic gene expression in the offspring. J Nutr 135:1382-1386
Lillycrop KA, Rodford J, Garratt ES, Slater-Jefferies JL, Godfrey KM, Gluckman PD, Hanson MA, Burdge GC (2010) Maternal protein restriction with or without folic acid supplementation during pregnancy alters the hepatic transcriptome in adult male rats. Br J Nutr 103:1711-1719

Martinez-Hernandez A, Enriquez L, Moreno-Moreno MJ, Marti A (2007) Genetics of obesity. Public Health Nutr 10:1138-1144

Mazmanian S (2010) Has the microbiota played a critical role in the evolution of the adaptive immune system? Science 330: $1768-1773$

McFall-Ngai MJ (2002) Unseen forces: the influence of bacteria on animal development. Dev Biol 242:1-14

McGowan PO, Sasaki A, D’Alessio AC, Dymov S, Labonté B, Szyf M, Turecki G, Meaney MJ (2009) Epigenetic regulation of the glucocorticoid receptor in human brain associates with childhood abuse. Nat Neurosci 12:342-348

Miyakawa H, Imai M, Sugimoto N, Ishikawa Y, Ishikawa A, Ishigaki H, Okada Y, Miyazaki S, Koshikawa S, Cornette R, Miura T (2010) Gene up-regulation in response to predator kairomones in the water flea, Daphnia pulex. BMC Dev Biol 10:45

Morange M (2011) Development and aging. Biol Theory. doi: 10.1007/s13752-011-0010-6

Moscona AA, Monroy A (eds) (1966) Current topics in developmental biology, Vol 1. Academic Press, New York

Myers JP, Zoeller RT, vom Saal FS (2009) A clash of old and new scientific concepts in toxicity, with important implications for public health. Environ Health Perspect 117:1652-1655

Nicoglou A (2011) Defining the boundaries of development with plasticity. Biol Theory. doi:10.1007/s13752-011-0003-5

Oberdörster E, McClellan-Green P (2002) Mechanisms of imposex induction in the mud snail, Ilyanassa obsoleta: TBT as a neurotoxin and aromatase inhibitor. Mar Environ Res 54:715-718

Pembrey ME (2010) Male-line transgenerational responses in humans. Human Fertility 13:268-271

Pradeu T (2011). A mixed self: The role of symbiosis in development. Biol Theory. doi:10.1007/s13752-011-0011-5

Relyea RA, Hoverman JT (2003) The impact of predators and competitors on the morphology and fitness of juvenile treefrogs. Oecologia 134:596-604

Rosenberg E, Sharon G, Zilber-Rosenberg I (2009) The hologenome theory of evolution: a fusion of neo-Darwinism and Lamarckism. Environ Microbiol 11:2959-2962

Saffo MB (2006) Symbiosis: the way of all life. In: Seckbach J (ed) Life as we know it. Springer, New York, pp 325-339

Skinner MK, Manikkam M, Guerrero-Bosagna C (2010) Epigenetic transgenerational actions of environmental factors in disease etymology. Trends Endocrinol Metab 21:214-222

Soto AM, Sonnenschein C (2010) Environmental causes of cancer: Endocrine disruptors as carcinogens. Nat Rev Endocrinol 6:363-370

Su JG, Jerrett M, de Nazelle A, Wolch J (2011) Does exposure to air pollution in urban parks have socioeconomic, racial or ethnic gradients? Environ Res 111:319-328

Sun J (2010) Enteric bacteria and cancer stem cells. Cancers 3:285-297

Vandenberg LN, Maffini MV, Schaeberle CM, Ucci AA, Sonnenschein C, Rubin BS, Soto AM (2008) Perinatal exposure to the xenoestrogen bisphenol-A induces mammary intraductal hyperplasias in adult CD-1 mice. Reprod Toxicol 26:210-219

Vermorel M, Lazzer S, Bitar A, Ribeyre J, Montaurier C, Fellmann N, Coudert J, Meyer M, Boirie Y (2005) Contributing factors and variability of energy expenditure in non-obese, obese, and postobese adolescents. Reprod Nutr Dev 45:129-142

Vom Saal F et al (2007) Chapel Hill bispenol-A expert panel consensus statement: integration of mechanisms, effects in animals, and potential to impact human public heath at current 
levels of exposure. Reprod Toxocol 24:131-138 thirty-five others

Voog J, Jones DL (2010) Stem cells and the niche: a dynamic duo. Cell Stem Cell 6:103-115

Wadia PR, Vandenberg LN, Schaeberle CM, Rubin BS, Sonnenschein C, Soto AM (2007) Perinatal bisphenol A exposure increases estrogen sensitivity of the mammary gland in diverse mouse strains. Environ Health Perspect 115:592-598

Walker DM, Gore AC (2011) Transgenerational neuroendocrine disruption of reproduction. Nat Rev Endocrinol 7:197-207

Wallace I, Wallace A (1979) The Two. Bantam Books, New York
Weaver IC (2007) Epigenetic programming by maternal behavior and pharmacological intervention. Nature versus nurture: let's call the whole thing off. Epigenetics 2:22-28

Weaver IC, Cervoni N, Champagne FA, D'Alessio AC, Sharma S, Seckl JR, Dymov S, Szyf M, Meaney MJ (2004) Epigenetic programming by maternal behavior. Nat Neurosci 7:847-854

Weiss PA (ed) (1956) The developmental biology conference series. University of Chicago Press, Chicago

Weiss PA (ed) (1959) Developmental biology. Academic Press, New York 